\title{
Construction of Teaching Team of Fine Arts Majors in Colleges and Universities
}

\author{
Ping Zhao \\ College of Art \& Design, Zaozhuang University, Zaozhuang 277160, China \\ 1665631686@qq.com
}

Keywords: Team; Construction; Creative; Higher Education

\begin{abstract}
The construction of teaching team in Colleges and universities plays an important role in improving teaching quality and training creative talents, which is of great significance for deepening the reform of higher education in China and improving the quality of education and teaching. The article analyzes the necessity of strengthening the construction of teaching team in colleges and universities, and probes into the construction and operation mechanism of teaching team.
\end{abstract}

\section{Introduction}

Team work mode which is essentially different from the individual work mode and competition mode is more emphasized on the cooperation and coordination with team members at work[1]. In today's colleges and universities, whether in the field of teaching, scientific research or administrative management, we can not only rely on individual strength, but we must also rely on collective strength, the trust and cooperation of team members[2]. In improving the quality of colleges and universities, the high level teaching team and teaching body is the key to improve teaching quality and strengthen teaching innovation[3].

\section{Connotation of Teaching Team}

Professor Chen Shiping pointed out that A team is a small group of people who work closely together and are responsible for each other[4]. They have common goals, performance evaluations, and work methods that are self - contained. Teams generally have 5 basic components, namely "5 p".

Purpose. A team should have a common and clear goal to guide team work.

People. People are the core strength of a team. In order to unify the team's thinking and coordinate their work, the team is generally no more than 10 people; in terms of personnel structure, their knowledge and skills complement each other as much as possible in order to better achieve teamwork and collaboration.

Positioning. It has two meanings: First, the overall positioning of the team, to define the current position of the team, the rights and obligations of the team, and who should be responsible for the team and so on. Second, individual positioning of members, to define what role members play in the team, whether they are planners or executant.

Power. To define the authority of a leader in a team. The team leader's authority size is related to the development stage of the team. Generally speaking, in the early stages of team development, the leadership is relatively concentrated, and as the team matures, leaders will have less and less rights.

Plan. A positive team can inspire the confidence of each individual, a team full of fighting spirit can inspire everyone's enthusiasm, and an innovative team can provide enough space for every member of the creativity. Our students also need teamwork in their studies and their future work. As teachers in colleges and universities, it is necessary to develop and cultivate their team spirit in order to verify and train students' team spirit. Therefore, the construction of teaching team in colleges and universities is of special significance. 


\section{The Connotation of Teaching Team}

According to the above description of team concept, the teaching team can be defined as: taking teaching work as the main line, the advanced educational idea as the instruction, focusing on professional construction, curriculum construction and teaching base construction, based on improving the quality of talent training, the teaching team is the core team of teaching research and teaching innovation. It has the following four aspects.

Definite Teaching Goals. The teaching team should aim at the construction of basic teaching projects such as school professional construction, curriculum construction and construction of teaching base, and carry out teaching research, carry out teaching innovation, and improve the teaching level and quality of teaching staff in a planned and phased way. The teaching team should play a role in the construction of characteristic specialties, the construction of excellent courses, the construction of excellent teaching materials and the practice teaching reform program at the school level, provincial level and even the national level.

Distinct Team Spirit. Teams are different from departments or groups, and are different from groups. A team is essentially a spirit of mutual assistance and collaboration, a willingness to cooperate and work together to achieve a common goal.

Reasonable Teaching Echelon. Reasonable teaching echelon is the foundation of forming and constructing teaching team. The teaching team should be led by a famous teacher, with the backbone of young and middle-aged teachers as the main body, consisting of professors, associate professors, lecturers, teaching assistants and teaching assistants. The team should have both experienced teachers with excellent teaching results and scientific research backbone.

Good Teaching and Construction Results. Good teaching achievement is the index to evaluate the effect of teaching team construction. The teaching team should strive for the landmark achievements at the university, provincial, or national level, such as teaching achievement awards, excellent courses, features or teachers' majors, experimental teaching, teachers' training centers and so on, showing a good tendency to achieve excellent results.

\section{The Platform Construction of Teaching Team}

After in-depth understanding of the teaching team, I think that most of the local universities have not formed a prominent teaching team of art majors. With the continuous expansion of the teaching staff, the continuous improvement of teaching management, the team formed by the teaching and research department is gradually moving towards a perfect teaching team. In accordance with the previous school construction, teaching assistants work alone, No instructors have been integrated into the teaching and research section, this is where the personnel will adjust their attention later. These efforts are far from enough without doubt. In order to optimize the educational reform, to improve the teaching quality of fine arts specialty, it is imperative to build even a few good teaching teams.

First of all, in order to grasp the construction platform of teaching team, the teaching team can be an excellent teaching group formed naturally in the course of teaching, and can also be a teaching group formed around a major school teaching project. In any case, the formation or construction of teaching team needs many platforms, such as specialty construction, curriculum construction, practice base construction and teaching management construction.

Professional Construction. Professional construction is the most basic and important content of teaching construction in colleges and universities, and is also the primary content of the construction of quality project in colleges and universities. Professional construction reflects the level of a school and the pattern of talent training, determining the development direction and competitive strength of the school. Therefore, the construction of teaching team should focus on the construction of fine arts. Taking professional construction as the link and the breakthrough point, in accordance with the advantages of fine arts prominent, distinctive features, social needs and other characteristics, the professional construction of elective courses should be strengthened, the professional structure should be optimized, and teachers and teams should be encouraged to actively declare school level, provincial, national brand, 
specialty, demonstration profession, making Professional construction become an important platform for the construction and development of teaching teams.

Curriculum Construction. Curriculum construction is also an important part of the basic construction of teaching, which includes curriculum system construction, teaching material construction, teaching content, reform of teaching methods and means, etc. According to the development trend of higher education, the direction of the school's professional development and the requirements of the society for talent training, on the basis of professional connotation development and talent training target, any teaching team should integrate curriculum resources, Actively promote the construction of curriculum system, reform curriculum teaching content, teaching methods and means, vigorously promote the school, provincial, national three quality course construction to give full play to the guidance and radiation of excellent courses.

Practice Base Construction. Practice teaching is an important aspect of teaching work in colleges and universities, which is an important way to train students' practical ability, creative ability and teaching quality. Universities should integrate the whole school resources, and should make efforts to build a number of influential practical teaching demonstration centers, providing an important platform for the construction of practical teaching team with practical teaching as the main task.

Construction of Teaching Management. Scientific, standardized and effective teaching management is an important condition for the construction and management of teaching teams. In the construction of teaching team and the teaching process of teaching team, a variety of problems need to be solved, such as the division and integration of personnel, the division of funds, the coordination of relevant departments in the work, etc., which needs scientific, standard and effective teaching management as the platform in addition to the need for sound management programme.

\section{The Suggestions for Construction of Teaching Team}

What's more, the construction of many high level teaching team is the key to improve teaching quality and train high-quality talents, and thus suggestions can be made on the following aspects to strengthen the teaching team building:

Training and Introducing Famous Teachers. The so-called "famous teachers" means that they have rich teaching experience and teaching results with advanced attainments in higher education research. Famous teachers, who are different from scientific research leaders, do not necessarily have significant scientific research results, but have made great achievements in professional construction and teaching innovation. With qualities of rigorous scholarship, good cooperation and dedication, famous teachers are the leader of the teaching team, leading the direction of teaching reform and construction.

Establishing Teaching Team Taking Curriculum as the Core. The real teaching team should break the division of the team members, and organize team members at the core of the curriculum. Teachers may come from different teaching or research departments or even different majors. The teaching team established in this way can better break through the intervention of the administrative system, and can play the special skills and advantages of the members on the core task of the team improving the teaching effect. For example, in the teaching of fine arts teaching team building, 1-3 responsible teachers can be respectively transferred from the traditional Chinese painting, oil painting, public teaching and research section to form an art education team including all directions of art studies (traditional Chinese painting, oil painting, and basic theory courses).

The Construction of Teaching Team of Different Levels. On the basis of the construction of college teaching team, a group of good teaching teams with good work base, clear goals, obvious results and good development trend should be fostered. Participating in provincial and national teaching team reporting and construction, different levels of teaching teams should be given different policy support and financial support. Teachers with certain development potential and clear direction should be timely selected to form new terms and be given purposeful support and training.

Creating a good Atmosphere for the Teaching Team Building. School leaders should set an example to create a good atmosphere for the teaching team building within the limits of your abilities, including providing a loose policy environment, good work platform, sufficient hardware and software 
conditions and thoughtful and meticulous service, and etc. Team members are called to form a fully inclusive and equitable cooperation, speak freely, work atmosphere, making it possible for everyone to give full play to the advantages.

Strengthen the Management of Teaching Team. colleges and universities should strengthen the management of teaching team, making the teaching team develop in an orderly and healthy way, and giving play to the advantages and functions. To pay attention to the daily management of the teaching team. Colleges and universities shall organize experts to evaluate the teaching team's development goals and plans, review the use of funds and evaluate phased results, incorporate a better team into the funding scheme to promote the further development of the teaching teams. The teaching team itself can adopt the combination of objective management and process management strengthening internal management and construction to ensure the positive operation of the team.

Establishing a Scientific Incentive and Restraint Mechanism. Scientific and rational incentive mechanism can mobilize team members to work hard to achieve a common vision promoting the healthy development of teaching teams.

Constructing an Institutionalized Teaching Team. The construction of a teaching team is a process of reintegration and optimization of human resources and teaching resources. Strengthen the system construction can make it possible for the teaching team to be a stable, healthy development team, and the establishment and development of teaching teams are not changed by people.

Strengthen the Guiding Function of Teaching Team. Last but not least, to give full play to the guiding role of the teaching team in college students' learning. Whether a teaching team is successful or not, it is not only reflected in its teaching level and teaching results, but also reflected in its educational level, the ability and effectiveness of learning guidance for college students. The teaching team should give full play to the advantages of professional development, curriculum teaching, practical training and theoretical improvement, to conduct comprehensive study guidance for college students. Meanwhile, under the guidance of team teaching masters, academic leaders and team spirit, students can be encouraged to learn professional knowledge and skills, improve their morality. Guiding students to practice long-term learning, the teaching team should also focus on improving the self-learning ability of students, especially the awareness of information. Mastering information retrieval skills, students can always get information smoothly, and renew the knowledge structure to realize the goal of lifelong learning. How to give full play to the role of teaching teams in college students' learning guidance is a subject worthy of study in the new situation. Only by building and managing the teaching team, improving the quality of the teaching staff, can more excellent and useful talents be cultivated for the country, a solid foundation for the sustained and long-term improvement of the quality of college education and teaching be laid, the function of "university" be truly realized.

\section{References}

[1] L.P.Feng, T.Li, H.Q.Liu, K.Xie. Research on computer network courses teaching based on constructivist learning theory[A]. Proceedings of the International Conference on Future Communication, Information and Computer Science (ICFCICS 2014)[C]. 2014

[2] Xu Hongyan, Wu Zhiming, Lin Tao, Tang Ningjiu, Chen Yu. Research on Teaching Model of Project-driven HCI Course[A]. Proceedings of 2016 3rd International Conference on Education, Management and Computing Technology (ICEMCT 2016)[C]. 2016

[3] Huijuan ZHAO, Yijing XU. Principle of University General Education Curriculum[A]. Proceedings of 2015 Joint International Social Science, Education, Language, Management and Business Conference (JISEM 2015)[C]. 2015

[4] S.P.Chen, X.M.Jiang, C.Li and Y.Xu. Practice teaching reform of engineering majors in local colleges and universities, Research and exploration in laboratory, 32(2013) 186-190. 